\title{
Intraocular Pressure Rise
}

National Cancer Institute

\section{Source}

National Cancer Institute. Intraocular Pressure Rise. NCI Thesaurus. Code C50618.

Increased pressure of the intraocular fluid in the eye. 